\title{
The Emergence of Hard-Line Islamic Idiology: Impact of Differences Understanding Discourse on the Qur'an
}

\author{
Mas'an Hamid \\ Prof at Faculty of Arts And Humanities, State Islamic University of Sunan Ampel Surabaya Indonesia
}

\begin{abstract}
The reasons for the differences in the understanding of discourse in the text of the Qor'an which raises the movement of Islamic ideology is: a. Internal factors causing the text bring ambiguous meaning; $b$. Theoretical approach used by Islamic scholars; c. the different abilities toward Arabic language; d. grade of different readers acceptance; e. The external factors relating to the purpose of providing a holistic meaning, such as: the interests of political, economic, social and cultural. This research is a qualitative research method that is ideographic language Sociology approach, because the study involves aspects of language and social, so that there is a difference of discourse. Implications of the new findings obtained from this study that a text when assessed or understood by a particular theoretical approach would result in an idea or a certain discourse anyway, because of the hidden meaning in a text has a certain tensile strength or power that can affect the psyche of the reader. Therefore, text language acquisition factors and intellect-mind of the reader becomes an important factor in understanding a text. If the sense-mind become deadlock, the speech, action, and statutes of the carrier text (Prophet Muhammad) can be used as a reference that is a support in understanding the text. Because of between three elements: the text and its carrier as well as the readers are always interrelated and inseparable, Thus, the results of this research is the development of the theory of pragmatics (Pragmatic Theory) in the study of language and literature, the reader is entitled to receive and interpret what he read.
\end{abstract}

Keywords: Hard-Line, Islamic Idiology, Difference Understanding, Qur'an, Impact

\section{INTRODUCTION}

There is a religious social phenomenon related to language, that is a different discourse in understanding the text of the Qur'an. Those differences begin caused by the way of text understanding done by Islamic scholars in different theoretical approach, so that the results of their thinking also be different too. on the one hand, these has a positive impact on the development of theories of science, because the theories are used in the understanding of the text so as to generate stability of thinking, and also bring Grace for the followers of the thinkers in general.

however, it also has a negative impact on the development of ideology, because the unity of Muslims becomes divisive, even bring up various streams or movements of Islamic groups, such as the hard-line Islamic group that occurred in the 1970s which is known as the Islamic Fundamentalist Movement (Arkom, 1992). This movement sustainably continues and changes the names, includes the last names of the most dangerous Islamic groups are "Islamic Jihad Groups" such as al-Qaeda and ISIS (Islamic State of Iraq and Syria) groups.

In the XXI M, many Muslims young were educated and trained to use weapons and assemble bombs, even their mentality was nurtured and influenced and convinced that those who dare to jihad by surrendering wealth and life will get the highest degree by Allah and also Will win (QS, 9: 20). The consolidation of Jihad idea continues to roll into other countries clandestinely including to Indonesia. The evidence is Dr. Azhari, Abdul Aziz (Imam Samudera), Ali Ghufron and Amrozi were directly involved in the Bali bombing tragedy in 2002, causing 212 deaths. Further events on Thursday, November 26, 2008, the Taj Mahal hotel in Mumbai India which was visited by many non-Muslim guests was bombed by Islamic militant groups who were ruled by Zakiyur-Rahman Lakhvi from Jama'atud Dakwah group which caused the death of 190 people. Likewise, Sri Lanka, on Tuesday, March 11, 2009, there has been a suicide bombing during the celebration of the Prophet's Mawl, followed by 6 Ministers and other important officials. The tragedy was made by a group of "Tamil Tigers" to the death of 14 people and 41 people severely injured.

In addition, in Indonesia there is also a movement that appears in order to defend Islam, such as Hizbut Tahrir Indonesia (HTI) and Islamic Defenders Front (FPI). Members of the group are very angry if the Islamic precepts are harassed by certain parties, as seen in the "Monas Monument" Jakarta on $1^{\text {st }}$ June 2008 when FPI clash with the National Alliance Group. The incident resulted one of the FPI figures, Habib Rizieq arrested. FPI group always praised the slogan: "The Noble Life or Death of Martyrs" ('Ish Kariman aw Mut Shahidan). Similarly event, on Friday, $17^{\text {th }}$ July 2009, there has been a bomb in Hotel J.W. Marriot and Ritz Carlton at Kuningan-Jakarta, which killed 9 people and 40 people seriously injured, the perpetrators of these events are 
The Emergence of Hard-Line Islamic Idiology: Impact of Differences Understanding Discourse of ..

still under Densus 88 and national police investigation. In fact, recently the ISIS group fought and seized parts of Baghdad, Syria and Kobane to be an Islamic state or a state under Islamic rule. The existence of ISIS group movement has raised concern for state and government organizers, both developed and developing countries in the world, including Indonesia.

\section{A. Research Focus}

Concerning the reality of social phenomena in the form of differences discourse, then the focus of the issues raised in this study are:

1. Why does occur diffirent discourse among the Islamic thinkers in understanding the text of the Qur'an?

2. What kinds of Islamic ideologies appear as the impact of such discourse differences?

\section{B. Research Method}

The type of this research is a qualitative research, namely "A research method that produces descriptive data, in the form of writing or oral from the people or objects that can be observed" (Bodgan, 1975: 4). The use of this type ordering to find a theory based on data from the field called Grounded Theory (Nasution, 1983), especially related to the emergence of Islamic hard ideology movement as the impact of discourse differences in understanding the text of the Qur'an.

While the object of this study is the manuscript of the Qur'an consisting of 30 juz or 114 letters or 6236 verses, especially verses relating to jihad or struggle to defend the religion of God, as well as opinions of scholars who discuss in depth about the cause -which underlies the emergence of the flow or movement of hardline Islamic ideology and its developmental impacts in Muslim-majority countries.

\section{DISCUSSION}

\section{A. Causes of Discourse Differences in Understanding Al-Qur'an's Text}

The advancement of science and technology in XXI centuries of AD has brought a positive impact toward development of Islamic thought. The emergence of modern Islamic thinkers such as Sayyid Qutub, Nasr Hamid Abu Zayd, al-Jabiri, Muhammad Nasiruddin al-Albani, Thaha Husayn, Ibn Taymiyah, Ibn Qayyim alJawzi, Hasan Syahrur, Anwar al-Jundi, Mohammad Arkoun, Fazlur Rahman, Sayyed Hossein Nashr, MH Thabathaba'i, Edward W. Said, Schimmel Annemarie, Malik ben Nabi, Mahmud Abbas al-'Aqqad, Muhammad bin Alwi al-Maliki, Haurani, Tibawi, Abdel Malik, Karl Amstrong, and Hussein Haykal are in part to provide reinterpretation And criticism of the old product of Islamic thought influenced much by isra'iliyat stories. In other side, also help the spirit of Muslims to catch up from the progress of thinking other people outside of Islam.

Almost all the writings or works from modern Islamic thinkers show that among Muslim scholars themselves there has been a discourse difference in understanding the text of revelation in the form of the Qur'an. Discourse differences occur, among others, because the methodology or theories used as an approach in the process of understanding the text is different, especially when giving interpretation or interpretation of the verses that are global (Mujmal), vague (Mubham), ambiguous (Musytarak), similar (Mutasyabihat), and also verses containing foreign words (Gharib). the process of interpreting the text of the Qur'an, it is not enough just to use the theories of meaning ( $\left.m a^{\prime} n a\right)$ in the philosophy of language, such as Referential Theory, The Ideational Theory, Behavioral Theory, But also uses the Semantic Theory (Dalal Sciences), as well as the Stilistic Theory (Balagah / al-Muhassinat al-Ma'nawiyah), Philology (Fiqhul- Lughah), Structural Theory (Nahw/Sharf), Rhythmic Theory and Rhymes (Arudl (Qawafi), Linguistic Theory (Lughah), Theory of Translation (Harfiyah/Ma'nawiyah), Hermeneutic Theory (Theory of Tafsir / Ulum al-Qur'an), and Reconstruction Theory (Reinterpretation) to study the history of descending al-Qur ' (Asbab al-Nuzul).

Biside these theories, no less important is the theory of reading the seven Imams (Ilm al-Qira'at alSab'u), because many Muslims are wrong in understanding the text of the Qur'an due to lack knowing the history of reading, especially the history of Imam 'Ashim and Imam Nafi', for example:

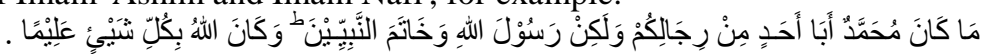

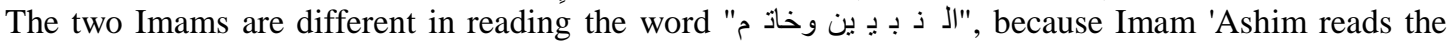
letter ta' with the fathah (خات م), while Imam Nafi 'reads the letter ta' with the alms harrah (خات مخ د) (ibnu sulaiman, 423).The impact of these different readings raises different meanings and interpretations among Islamic linguists and scholars. Some Exegesis Books writen by Ahlus Sunnah wal Jama'ah group, such as Ibn'Atiyah, alGhazali, al-Qurtubi, Abu Umar, Ibn Mas'ud, al-Rammani and al-Maraghi stated that the word الـ ذب د ين وخات م Is the end of the Prophets or the concluding of the Prophets. That is, "Muhammad is the last Prophet and after that there is no Prophet anymore" (abi, 1964). However, there are other groups such as the Ahmadiyya Qadiyani (journal, 2008) whose stating that the word "نال ذن بـ بي وخات م" means "Ring or symbol of the Prophets". That is, Muhammad is the leader of the Prophets, he is not the last Prophet, and afterwards there is another Prophet named Ahmad. As the saying of Allah (QS, 33: 40): 
The Emergence of Hard-Line Islamic Idiology: Impact of Differences Understanding Discourse of ..

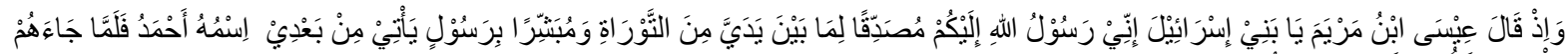

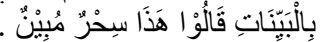

After knowing the verse, then they (Ahmadiyah group) believe that the meaning of the word "Ahmad" is "Mirza Ghulam Ahmad". In fact, Imam Malik bin Anas (179 AH) has stated in his statement that the meaning of the word "Ahmad" in the verse is Muhammad, because the Prophet Muhammad has five names; Muhammad, Ahmad, al-Mahi, al-Hasyir, And al-'Aqib, as al-Hadith (malik, 2002):

\section{B. Kinds of Islamic Ideology Emerged As the Impact of Discourse Differences}

Some movements of Islamic ideology that arise as a result of discourse differences toward Qur'an understanding are:

1. Traditionalist Islam

a. Conservative Traditionalists: movements whose religious insight is narrow, oriented towards the worship of Mahdlah only,

b. Post Traditionalist: movement with a wider religious insight, oriented to the worship of Mahdlah and Ghayru Mahdlah (social worship).

2. Modernist Islam

a. Reform Modernist: movement that makes Islam as a religion covering all the teachings in all aspects of life, such as: politics, economics, social, and culture, receptive to logical change and believes that the past is not everything.

b. Secular Modernist: movement that makes religion only regulates the matter of worship to God, while problems outside worship become human affairs with each other.

\section{Puritanist Islam}

Movement that make Islam a comprehensive teaching for all aspects of life, reject all Western products, and strongly criticize westernized people. In Indonesia, the influence of the West in the field of religion is quite interesting, namely to bring up the movement of reform and purification of shari'ah(islamic rule), such as Muhammadiyah for example, trying to purify the understanding and practice of shari'ah and distanced it from the tradition of life of Sufism which they value full of bid'ah (herey) and khurafat (superstition). So, this kind of movement is a return to progressive Islam. However, their impressive activity is the success of offsetting Christians to make the flagship schools that Muslims can be proud of.

\section{Revivalist Islam}

a. Pra Modern Revivalist: appeared in the 18th and 19th centuries in Turkey, Saudi Arabia, India, and Africa. This period has characteristics: 1) There is a deep concern about the moral decline of Muslims; 2) There is an invitation to return to true Islam by means of ijtihad and discarding superstition; 3 ) There is an invitation to abandon the teachings of Jabriyah; 4) There is an invitation to implement renewal through the strength of weapons (jihad).

b. Classic Modernist: appeared in the mid-19th and early 20th century AD its characteristics are: 1) His thinking is influenced by Western ideas; 2) There is an effort to expand ijtihad, such as on the relationship of revelation, reason, and social renewal.

c. Neo Revivalist: In this period came the idea of establishing democracy and Islamic education, because Islam is considered capable of answering all the challenges of the times. The characteristic of this period is to try to distinguish itself from the Wes

d. Neo Modernist: Neo modernism seeks to develop: a) Critical attitudes toward the West and the legacy of prosperity; b) Muslims should study the West objectively, as well as on the teachings of Islam itself; c) A thorough and systematic review as a guide for the future.

5. Mohametis Islam

The characteristics of this group are all its activities in the name of "Islam". The goal is to protect themselves, feel safe, and attract the masses by using the label "Islam", either individually or institution, such as: Islamic Politics, Islamic Economics, Islamic Sociology, Islamic Culture, Islamic Medicine, Islamic Education, and so on. In fact, not all activities used Islamic references. For example, nearly $40 \%$ of the literature in Islamic education libraries contains non-Muslim books whose contents sometimes deviate from the teachings of Islam.

\section{Fundamentalist Islam}

In the Islamic thought discourse, fundamentalists are defined by the term:

a. Ushuliyah: the one who hold strongly to the subjects of Islamic teachings, as set forth in the Qur'an and alHadith.

b. Al-Ushuliyah al-Islamiyah: the return to the faith fundament, the enforcement of the political power of the people, and the establishment of the legitimate principles of authority. 
The Emergence of Hard-Line Islamic Idiology: Impact of Differences Understanding Discourse of ..

Fundamentalism in Islam has existed since the Khawarijs proclaimed the teachings of La Hukma Illa Allah firmly and vehemently, and disbelieved those who were outside of his group. This group followed by Imam Ahmad bin Hambal in his teachings by announcing back to the Qur'an and al -Sunnah.

Hambali movement was followed by Muhammad bin Abdul Wahab in the 18th century, who in his movement opposed the things of local tradition, cleansed Islam from local traditions, and was very religious towards non-public teachings (later famous as Wahabi movement). This movement inspired Islamic figures of the 20th century, such as Abu al-A'la al-Mawdudi in Pakistan, Sayyid Qutub and Hasan al-Banna in Egypt (Ikhwanul Muslimin Movement), and also Imam Ayatullah Khomeeni in Iran. The characteristics of Islamic fight: First, the only Islamic teachings are the correct. Secondly, the teachings of Islam must be championed rigidly, literally, against the West and anti-modern programs.

\section{The Character of Sunni and Shi'i Fundamentalism}

a. Sunni: institutional with the aim of establishing an Islamic state by elite figures which are not from traditional conservatives, such as Abu al-A'la al-Maududi and Hasan al-Banna. Sunnis have never succeeded in establishing an Islamic state.

b. Shi'i: unorganized, populist from traditional and radical conservative camps. However, Shi'i succeeded in establishing the Islamic state (Republic of Iran).

\section{The attitude of Fundamentalism toward Religious Tradition}

a. Conservative fundamentalists claim that the earlier clerical tradition was judged the same as the Book.

b. Radical fundamentalists say they want to clear the influence of their predecessors in understanding the scriptures.

\section{Fundamentalist Difference from Modernist}

Modernists tend to interpret the doctrine elastically and flexibly, whereas fundamentalists tend to interpret the doctrine rigidly and literally, such as al-Da'wah ila al-Tawhid (Wahabi) movement in Saudi Arabia, and the Sanusiah movement in Cyrenaika. Both of these movements do have different characters, if the first is the salaf flow and cling to the school Hambali, then the second is to tolerate sufism and the form of semitarikat. However, the methods and characteristics of the two movements are the same, ie establishing an organized and moving group to achieve the goal by taking the path of radical rapid change (revolution).

\section{Some Fundamentalist Movements}

Included in this category of hard-line Islamic groups are:

\section{1) Al-Da'wah ila al-Tawhid (Wahabi) Movement in Saudi Arabia}

The founder of this movement is Muhammad bin Abdul Wahab. The event behind the birth of this movement is the deviance of the Muslims in the field of tawhid as follows:

a) The tomb of Prophet Muhammad SAW is fenced and decorated to be the object of ritual;

b) Husin's grave become the center of Shia worship.

c) The fruit of "tasbih" has been made in completeness in the tasbih.

d) The Muslims followed and fought the opinion (madhhab) of the 'ulama in taqlid rather than following the Prophet's footsteps.

According to Abdul Wahab, the essence of Islam is monotheism, because the teachings of tauhid are commanded by Allah to be obeyed by the jinn and human beings. Tauhid should be the basis and motivation of all human behavior and deeds. All acts of worship, faith, and ihsan must be based on monotheism. Therefore, the movement's efforts are to:

a) Reject all forms of worship, both to the Prophet and to the guardian. The person who does it is an unbeliever.

b) Honoring the grave, moreover praising it is shirk, because it is opposed to tauhid even though it is the grave of the Prophet.

c) Graves for places of worship, such as prayer, tawaf, i'tikaf and reciting al-Qur'an done by shufi are prohibited.

d) Asking syafa'at on the guardians is a shirk, because syafa'at is only the right of Allah.

e) Blind Taqlid is haram, because opposed to tauhid.

f) Reject intellectualism, such as philosophy and theology, both taught by mutakallim and Shi'ah.

In $1744 \mathrm{AD}$ there was an agreement between Abdul Wahab and Muhammad Ibn Sa'ud. This fellowship was exacerbated by a marriage between Ibn Abdul Wahab's daughter and Ibn Sa'ud's son. This covenant and marriage between these two families has been a supporter of the Saudi state until now, and Wahhabism is prevalent in Arabia until now. 
The Emergence of Hard-Line Islamic Idiology: Impact of Differences Understanding Discourse of..

2) Usman dan (Ibn) Fodio Movement inNigeria

This movement was founded by Usman and (Ibn) Fodio. The movement seeks to restore Islam from individual beliefs to religious law, an attempt to clean up the pieces of traditional habits and to build a theocratic state. For his services Usman and Fodio got the title Shehu (Shaykh), Nuruzzamani (Light of the Times), Shehu Malamin Malamui (Master of the Great Teachers), Malamin Abin Cost (Master who works in a better morale), Gigamin Uban Tumbura (voice defeated all the other drums).

The difference between Usman and Fodio with Ibn Abdul Wahab is that if Ibn Abdul Wahab attacked sufism and dismantled the grave buildings, then Usman and Fodio taught Sufism.

\section{3) Mujahidin and Al-Fara'idli in India}

The Muslims in India in the 19th century AD face three major problems:

a) Religious experiences not only derived from the Qur'an and hadith, but have been mixed with Hindu culture and beliefs.

b) The divisions among the Muslims that caused their position to become weak, after the withdrawal of the Mughal empire with the death of Awrangzib in $1701 \mathrm{AD}$

c) The establishment of established British rule in Bengal.

In the face of these conditions, three figures emerged: 1) Shah Abdul Aziz in Delhi, 2) Sayyid Ahmad Syahid in Pradesh, 3) Shari'atullah Hajj in Bengal, they invaded the Muslims to cleanse the aqidah.

a) Mujahidin Movement in India

This movement was founded by Sayyid Ahmad Syahid which has two purposes: first, stopping threat of foreign domination, including fighting Sikhs who have seized the role of Muslims in North India. Second, Stemming the decline of Islam by cleansing tauhid.

b) Fara'idli Movement in Bengal

The movement was founded by Haji Shari'atullah with the aim of cleansing tauhid and against oppression, he is anti-Sufism and Shi'i, he called on the Muslim community in Bengal to live by imitating the behavior of Muslim society during the time of Khulafa 'al-Rashidin.

\section{4) Sanusiah Movement at Aljazair (Tripolitania)}

This movement was founded by Muhammad Ibn Ali al-Sanusi. The approach used is sufism, Through the ways:

a) Establish a brotherhood aimed at raising Muslims against poverty and oppression, on the basis of believing in oneself by sticking to the pure and simple teachings of religion;

b) Tend to unity by peaceful means;

c) Call on the ummah to cling to the Qur'an and al-Sunnah, but tolerate respect for the guardian, for he does not want disputes in society;

d) He rejects the strange music and movements that accompany the dhikr;

e) Encourage his students to eat well, dress nicely, and use perfumes;

f) To realize his ambitions, Zawiyah (vellage) is established in fertile places throughout Libya to Makkah which is equipped with government equipment, mosques, schools, student dormitories, khalwat spaces, and hotels, and so on.

g) Sanusiah took the lead in opposing British colonialism.

\section{5) Paderi Movement in West Sumatra}

The movement was founded by Haji Miskin, Haji Sumanik and Haji Piobang, in 1803 AD This movement was inspired by the Wahabis in Mecca when they perform the pilgrimage, the purpose:

a) Cleaning tauhid from all kinds of dirt;

b) Expel the Dutch and British colonizers who have been covered in the body of the adat.

This movement was born backed by:

a) The Minangkabau Society is in moral decadence;

b) The king and the adat no longer think of the people and shi'ar of religion, because cool with the joys and luxuries of life;

c) Immunity is rampant, such as: drinking wine, donating, playing gambling, chicken piercing, adultery and others.

d) The weakness of the ulama's position compared to the adat and the king.

In order to repair the defaced society, the Padrians established their identity as follows:

a) Men should have beards and wear white-clothes;

b) Women should wear veils;

c) If the walk, eye should be straight ahead;

d) Wear white robes until feet, "tasbih" pieces in left hand, sword in right hand,

e) Scholars (Ulama) should carry a Qur'an that placed on a red bag and hung on the neck; 
The Emergence of Hard-Line Islamic Idiology: Impact of Differences Understanding Discourse of ..

f) To fight for his ideals, the Padrians fought against England, the Netherlands, and the adat. The Resistance of the Padrias ended when Tuanku Imam Bonjol was defeated by the Dutch in 1837 AD.

By looking at the various forms of fundamentalist movements, it can be concluded that the fundamentalist movement emerged as a reaction to the circumstances of Muslims who practice the teachings of Islam (tauhid) is not pure anymore and live in a state of ignorant, poor, backward, and oppressed.

6) Jamaah Islamiyah Movement in Pakistan

Jema'ah Islamiyah is an association of Muslims or Jam'iyah Ulama in Pakistan. Established by alMawdudi. The principle of the movement is to establish a state that implements the Islamic Shari'ah and rejects the kafir state. Jema'ah Islamiyah is supported by two important components, namely Jihad and Takfir wa al-Hijrah. These two movements arise because of social and economic disparities. There are two basic differences between Jihad and Takfir wa al-Hijrah, namely:

a) Jihad fight collectively with the leadership of Umar Abdurrahman, while Takfir wa al-Hijrah fight collectively and individually through a charismatic leader named Shukri Mustafa.

b) Jihad do in spontaneously, while Takfir wa al-Hijrah does not engage in a revolutionary political movement, except after has strongth.

The characteristics of Jema'ah Islamiyah group is very persistent and courageous in defending Islam, they are not half-hearted in defending Islam, if Islam is harassed by anyone, especially by non-Muslims. In Afghanistan and India they are nurtured, trained and educated to their conscious and steady belief that those who struggle for the uprightness of Allah's religion and against the enemies of Islam are an honor, for they will gain a high degree of triumph and victory with Allah, as Allah say:

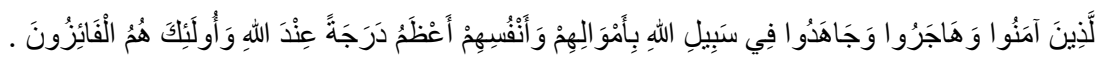

"Those who believe and emigrate and jihad in the way of Allah with their possessions, things and selves (soul), are higher in the sight of Allah; And that is the people who got the victory." (QS, $1413 \mathrm{H}$ )

whereas, The goal is to get God's grace, as Allah's word

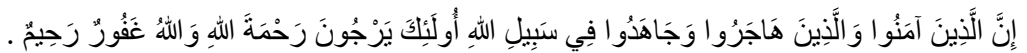

"Those who believe, those who emigrate, and strive in the way of Allah, they expect the grace of Allah, and Allah is Forgiving, Merciful"

\section{7) Al Qaeda in Saudi Arabia}

Al-Qaeda is a twentieth-century fundamentalist phenomenon whihc consisting of veteran Islamiic fighters, Jema'ah Islamiyah, and Ahlul Ansar led by Osamah bin Laden. The target of al-Qaida's struggle was to cooperate with Saudi Arabia in attacking the United States, but in 1994 he was expelled from Saudi Arabia and settled in Sudan. These al-Qaeda members are between 300-500 thousand people spread across Afghanistan, Pakistan, Yemen and Saudi Arabia. This movement aims to establish an Islamic state. The method used is "terror" against Western and US interests. Actually, the behavior of "terror" is sowed by the US to legitimize security measures against its interests.

\section{8) Islamic State of Iraq and Syria (ISIS) Movement in Baghdad}

This movement emerged in Iraq under Abu Bakar al-Baghdadi, inaugurated on October 10, 2010 and commenced its activities in 2012 by recruiting young people from various Islamic countries to be educated and mentally trained to follow in their footsteps. The existence of the ISIS group movement raises pros and cons among the Muslims, as their struggle fights and seizes the territories occupied by Muslims. In fact, they have tried to control the areas or areas of the Muslims, such as: Iraq, Syria and Kobane are planned to be an Islamic state (Dawlah Islamiyah).

The pros and cons of the ISIS movement were discussed about its existence and its future by Indonesian Muslims, including by Kyai and academics, at the Hasyim Muzadi Ponpes al-Hikam, Depok Jakarta, and attended by \pm 400 people. The results of the meeting stated: "What the ISIS people do does not reflect the true Islam"(jawa post, 2014). Therefore, this information should be disseminated to the community in order to create a peaceful religious atmosphere.

The emergence this movement bisedes motivated by the existence of external factors that are holistic, such as: political interests, economic, social, cultural and the threat to Islam and Muslim life, also driven by the internal psychological factors of Muslims themselves, Feel the most correct in understanding the text of the Qur'an and the Sunnah of the Prophet and considered wrong to the ideas or results of other people's thinking. 
The Emergence of Hard-Line Islamic Idiology: Impact of Differences Understanding Discourse of ..

\section{CONCLUSION}

The causes of discourse differences in the understanding of the text of the Qur'an so as to bring the movement of Islamic ideology are: a) The existence of internal factors of text containing ambiguous words that give rise to a double understanding; B) The theoretical approach used by Islamic thinkers in understanding the text of the Qur'an varies; C) There is a different level of understanding of Arabic, and the depth of meaning of words or sentences they give is different too; D) The acceptance level of readers varies so much that they must choose the opinion that is most correct and best suited to their idea; E) External factors, namely the importance of giving meaning that is holistic, such as: political, economic, social, and cultural interests.

Some movements of Islamic ideology that arise as a result of discourse differences in understanding the text of the Qur'an are: a) The Movement of Traditionalist Islamic Groups; B) The Movement of Modernist Islamic Groups; C) Puritanical Islamic Movement; D) Movement of Revivalist Islamic Group; E) Movement of Islamist / Mohametis Group; F) The Movement of Fundamentalist Islamic / Hardline Islam Group which includes: 1) Al-Da'wah Movement of Ila al-Tawhid (Wahabi) in Saudi Arabia; 2) Utsman and Ibn Fodio's movements in Nigeria; 3) Mujahidin and Fara'idli Movements in India; 4) Sanusiah movement in Algeria (Tripolitania); 5) Padri movement in West Sumatra-Indonesia; 6) The Jema'ah Islamiyah Movement / Islamic Jihad Group in Pakistan which is now beginning to spread to Malaysia and Indonesia; 7) Al-Qaeda movement in Pakistan, Yemen and Saudi Arabia; 8) ISIS movement in Baghdad

\section{REFERENCES}

[1]. Mohammad Arkoun, Membongkar Wacana Hegemonik dalam Islam dan Post Modernisme, (Surabaya, al-Fikr, 1992), 209-270 al-Qur'an, 9: 20.

[2]. Al-Qur'an al-Karim, bi Riwayah Hafs bin Sulaiman Ibn al-Mughirah al-Asadi al-Kufi Liqira'ah 'Asim bin Abi al-Nujud al-Kufi al-Tabi'i, Surat al-Ahzab, 40, (Madinah al-Munawarah: Mujamma' Khadim alHaramayn al-Sharifayn al-Malik Fahd, $1413 \mathrm{H}), 423$.

[3]. Al-Qur'an al-Karim bi Riwayah Warash 'Al-Nafi', Surat al-Ahzab, 40, (Beirut: Dar Ibn Kathir, 1424 H / $2004 \mathrm{M}), 423$.

[4]. Abi Abd. Allah Muhammad bin Ahmad al-Ansari al-Qurtubi, Al-Jami li Ahkam al-Qur'an, juz 14, (Beirut: Dar al-Fikr, 1964), 196-197; Khalif Abd al-Rahman al-'Akk, Safwah al-Bayan li Ma'ani alQur'an al-Karim, (Beirut: Dar Ibn 'Usasah, 1994), 423; Ahmad Mustafa al-Maraghi, Tafsir al-Maraghi, juz 22, (Beirut: Dar al-Fikr, 1315 H), 16-17; al-Qur'an dan terjemahannya, 674.

[5]. Perkembangan Penanganan Ahmadiyah, dalam Ikhlas Beramal, Nomor 51, Tahun XI, (Mei, 2008), 2028. Al-Qur'an: 33: 40.

[6]. Malik bin Anas, Kitab al-Muwatta', (Beirut: Dar al-Fikr, 1422 H/ 2002 M), 610.

[7]. Al-Qur'an dan terjemahannya, (Kerajaan Saudi Arabia: Khadim al-Haramayn al-Sharifayn Fahd Ibn Abd al-Aziz al-Saud, 1413 H), 281. Ibid., 929.

[8]. Jawa Pos, Kamis, 30 Oktober 2014, p. 2 